\title{
Peptides derived from the integrin $\beta$ cytoplasmic tails inhibit angiogenesis
}

Zhongyuan $\mathrm{Cao}^{1,2}$, Xinfeng Suo ${ }^{2}$, Yudan $\mathrm{Chu}^{2}$, Zhou Xu², Yun Bao², Chunxiao Miao², Wenfeng Deng ${ }^{2}, \mathrm{Kaijun}^{2} \mathrm{Mao}^{2}$, Juan $\mathrm{GaO}^{2}$, Zhen $\mathrm{Xu}^{2,3^{*}}$ and Yan-Qing $\mathrm{Ma}^{1,2,3^{*}}$ (D)

\begin{abstract}
Background: Integrins are essential regulators of angiogenesis. However, the antiangiogenic potential of peptides derived from the integrin cytoplasmic tails (CT) remains mostly undetermined.

Methods: Here we designed a panel of membrane-penetrating peptides (termed as m $\beta C T P s$ ), each comprising a C-terminal NxxY motif from one of the conserved integrin $\beta C T$, and evaluated their antiangiogenic ability using both in vitro and in vivo approaches.
\end{abstract}

Results: We found that $\mathrm{m} \beta 3 \mathrm{CTP}, \mathrm{m} \beta 5 \mathrm{CTP}$ and $\mathrm{m} \beta 6 \mathrm{CTP}$, derived respectively from the integrin $\beta 3, \beta 5$ and $\beta 6 \mathrm{CTs}$, but not others, exhibit antiangiogenic ability. Interestingly, we observed that the integrin $\beta 3, \beta 5$ and $\beta 6$ CTs but not others are able to interact with $\beta_{3}$-endonexin. In addition, the antiangiogenic core in m $\beta 3 C T P$ is identical to a previously identified $\beta_{3}$-endonexin binding region in the integrin $\beta 3 C T$, indicating that the antiangiogenic m $\beta C T P S$ may function via their binding to $\beta_{3}$-endonexin. Consistently, knockdown of endogenous $\beta_{3}$-endonexin in HUVECs significantly suppresses tube formation, suggesting that $\beta_{3}$-endonexin is proangiogenic. However, neither treatment with the antiangiogenic m $\beta C T P$ s nor knockdown of endogenous $\beta_{3}$-endonexin affects integrin-mediated HUVEC adhesion and migration, indicating that their antiangiogenic effect may not rely on directly regulating integrin activity. Importantly, both treatment with the antiangiogenic m $\beta C T P s$ and knockdown of endogenous $\beta_{3}$-endonexin in HUVECs inhibit VEGF expression and cell proliferation, thereby providing mechanistic explanations for the functional consequences.

Conclusion: Our results suggest that the antiangiogenic m $\beta C T P s$ can interact with $\beta_{3}$-endonexin in vascular endothelial cells and suppress its function in regulating VEGF expression and cell proliferation, thus disclosing a unique pathway that may be useful for developing novel antiangiogenic strategies.

Keywords: Angiogenesis, Endothelial cells, Integrins, Cytoplasmic tails, $\beta 3$-endonexin

\section{Background}

Integrins are a family of cell adhesion receptors that primarily support cell interaction with extracellular matrix, thus being able to mediate cell adhesion and migration $[1,2]$. The integrins consist of non-covalently associated $\alpha / \beta$ subunits and are widely expressed. Among the integrin members expressed in vascular endothelial cells, $\alpha v \beta 3$ has been extensively investigated and well recognized as an antiangiogenic target [3-5]. It has been found that integrin $\alpha v \beta 3$ is prominently expressed in

\footnotetext{
* Correspondence: zhen.xu@bcw.edu; yanqing.ma@bcw.edu

${ }^{2}$ School of Life Sciences, Shanghai University, Shanghai, China

${ }^{1}$ School of Environmental and Chemical Engineering, Shanghai University,

Shanghai, China

Full list of author information is available at the end of the article
}

angiogenic vasculature and targetable to induce apoptosis of proliferative tumor endothelial cells [6-8], and these findings have sparked the antitumor stratagems by developing specific inhibitors that block $\alpha \mathrm{v} \beta 3$-ligand interactions. Practically, the integrin $\alpha v \beta 3$ antagonisms with either functional blocking antibodies or ligand-mimetic peptides have shown promising antiangiogenic and antitumor effects [9-11]. However, substantial controversies have arisen due to some inconsistent observations. First, enhanced tumor growth can be observed in integrin $\beta 3$-deficient mice [12]. Second, low concentrations of RGD-mimetic integrin $\alpha v \beta 3$ inhibitors unexpectedly promote tumor growth and angiogenesis in mice $[13,14]$. Adding further to these 
uncertainties is a study from Merck that Cilengitide, a highly anticipated integrin $\alpha v \beta 3$ antagonist, has failed its first Phase III clinical trial on treating glioblastoma [15]. Hence, these inconsistencies suggest that more studies are required in order to further optimize the therapeutic outcomes.

The integrin $\alpha / \beta$ cytoplasmic tails (CTs) are typically short (except for $\beta 4$ ) and lack intrinsic enzymatic activity, but they, especially the integrin $\beta$ CTs, play indispensable roles in the regulation of integrin bidirectional signaling via interacting with their cytoplasmic binding partners $[16,17]$. Each of the integrin $\beta$ CTs (except for $\beta 4$ and $\beta 8$ ) encompasses two conserved NxxY motifs, which constitute essential hubs for recruiting the $\beta$ CT binding proteins. For example, the membrane-proximal NxxY motif interacts with talin, a key integrin activator; and the C-terminal NxxY motif specifically binds kindlins, a family of essential integrin co-activators [18-20]. In addition, the C-terminal NxxY motif NITY in the $\beta 3$ $\mathrm{CT}$ is also involved in interacting with $\beta 3$-endonexin $[21,22]$. The kindlin family members (kindlin-1, -2 and -3) essentially support integrin-mediated cell adhesion and migration, and deficiency of any one of them leads to tissue-specific integrin dysfunctions [23]. It has been shown that the polypeptide $\beta 3$-endonexin can selectively interact with the integrin $\beta 3$ CT but not the $\beta 1$ and $\beta 2$ CTs $[21,22]$, but it still inconclusive if $\beta 3$-endonexin plays a role in regulating $\beta 3$-integrin activation $[20,22]$.

Kindlins and $\beta 3$-endonexin are both expressed in vascular endothelial cells [20, 24-27]. Kindlin-2 has been shown to support integrin $\alpha v \beta 3$-mediated endothelial cell adhesion and migration and promote angiogenesis in zebrafish and mice $[20,26]$. Interestingly, $\beta 3$-endonexin was ever reported to be able to negatively regulate the angiogenic response under hypoxic conditions [24]. Since both kindlins and $\beta 3$-endonexin recognize the $C$-terminal NITY motif of the integrin $\beta 3$ $\mathrm{CT}$, we hypothesize that the peptides comprising the NITY motif or its conserved counterparts in the other integrin $\beta$ CTs may have the ability to regulate angiogenesis. To test this posibility, we employ six membrane-penetrating peptides derived from the conserved integrin $\beta$ CTs, each embodying a C-terminal NxxY motif from one of the $\beta$ CTs, and evaluate their angiogenic capacity using in vitro and in vivo approaches, and finally disclose an important functional relationship between the integrin $\beta \mathrm{CT}$ peptides and $\beta 3$-endonexin in regulating angiogenesis.

\section{Methods}

\section{Proteins and peptides}

The GST-fused integrin $\beta$ CT proteins were expressed in E. coli BL21 (DE3) and purified by affinity chromatography of glutathione. All the integrin derived peptides used in this study were synthesized and purified to more than 98\%. The peptides were dissolved in DMSO at $100 \mu \mathrm{M}$ concentration and further diluted into culture medium to final concentrations when treating cells.

\section{Cell culture and transfection}

Primary human umbilical vein endothelial cells (HUVECs) were seeded in fibronectin coated tissue culture dishes and cultured in MCDB medium (Sigma) supplemented with 15\% FBS, endothelial cell growth supplements (Sigma) and heparin. Murine RM1 prostate cancer cells were cultured in DMEM/F12 medium (Hyclone) supplemented with 10\% FBS. All these cultures were maintained at $37{ }^{\circ} \mathrm{C}$ in a humidified tissue culture incubator with an atmosphere of $5 \% \mathrm{CO}_{2}$. Targefect reagents (Targeting Systems) were used to transfect HUVECs with siRNA duplex or $\beta 3$-endonexin plasmid for knocking down endogenous $\beta 3$-endonexin or overexpressing exogenous $\beta 3$-endonexin in HUVECs.

\section{In vitro HUVEC tube formation}

24-well tissue culture plates were pre-coated with $300 \mu \mathrm{l}$ per well of growth factor-reduced Matrigel (BD Biosciences). HUVECs $\left(0.25 \times 10^{5} /\right.$ well $)$ were seeded on the polymerized Matrigel in $3 \times$ diluted culture medium with or without the indicated $\mathrm{m} \beta \mathrm{CTPs}(20 \mu \mathrm{M}$ at a final concentration). After $8-12 \mathrm{~h}$ of incubation, capillary-like tube structures formed by HUVECs were examined under an inverted microscope.

\section{In vivo Matrigel plug assay}

Aliquots of liquid Matrigel (BD Biosciences) supplemented with $600 \mathrm{ng} / \mathrm{ml}$ of bFGF and $100 \mathrm{U} / \mathrm{ml}$ of heparin were mixed with the indicated $\mathrm{m} \beta C T P s(50 \mu \mathrm{M}$ at final concentration) and injected into $\mathrm{BALB} / \mathrm{c}$ nude mice subcutaneously. Matrigel mixture without the peptides was used as a control. Matrigel solution can quickly polymerize to form a solid plug after subcutaneous injection. 7 days after the injection, the Matrigel plugs were carefully harvested from mice for quantification of hemoglobin and histological staining.

\section{Solid tumor growth model}

In vivo tumor growth was achieved by subcutaneously implanting murine RM1 prostate cancer cells into $\mathrm{BALB} / \mathrm{c}$ nude male mice $\left(1.2 \times 10^{6}\right.$ cells per mouse). Starting from day 5 after cancer cell inoculation, $\mathrm{m} \beta \mathrm{CTPs}$ or saline alone was intratumorally administrated every other day $(50 \mu \mathrm{M}$ at a final concentration, $100 \mu \mathrm{l}$ per mouse). Meanwhile, tumor volumes (v) were determined by measuring the length (l) and the width $(w)$ and calculated using the following formula: $\mathrm{v}=0.52\left(1 \times \mathrm{w}^{2}\right)$. Eventually, the tumor tissues were carefully isolated and processed for histological studies. 


\section{HUVEC proliferation analysis}

Cell proliferation was measured by the CCK- 8 Cell Counting Kit (Dojindo) according to the manufacturer's instruction. In brief, HUVECs were seeded in 96-well plates at a density of $8 \times 10^{3} /$ well and treated with the indicated peptides for $48 \mathrm{~h}$ under culture conditions. After that, cells were incubated with the CCK-8 solution for $3 \mathrm{~h}$ and the absorbance at $450 \mathrm{~nm}$ was measured using a microplate reader. For some experiments, the MTT assay (Sigma) was also performed to confirm the results.

\section{HUVEC adhesion and migration}

HUVECs were pretreated with the tested peptides for $2 \mathrm{~h}$ and their effects on cell adhesion and migration were evaluated as we previously described [20]. For measuring HUVEC adhesion, HUVECs were allowed to incubate with immobilized fibrinogen or vitronectin in slide chambers in the presence or absence of VEGF $\left(20 \mathrm{ng} / \mathrm{ml}\right.$ ) for $30 \mathrm{~min}$ at $37{ }^{\circ} \mathrm{C}$. The suspended cells were washed away and the adherent cells were fixed by $70 \%$ methanol and stained with $1 \%$ toluidine blue for visualization. HUVEC migration was evaluated using Transwell plates with $8 \mu \mathrm{m}$ pore size. HUVECs were added to the upper chamber that was precoated with either fibrinogen or vitronectin and allowed to migrate for $8 \mathrm{~h}$ in the presence or absence of VEGF $(20 \mathrm{ng} / \mathrm{ml})$ in the lower chamber. After migration, the cells on the upper surface of the chamber were removed and the migrated cells on the bottom surface were fixed with methanol and stained with $1 \%$ toluidine blue for performing microscopic cell counts.

\section{Yeast two-hybrid}

To test the interaction of $\beta 3$-endonexin or kindlin-2 with the integrin $\beta$ CTs, the Matchmaker ${ }^{\mathrm{m}}$ Gold Yeast Two-hybrid system (Clontech) was employed as we previously described [28]. In brief, $\beta 3$-endonexin or kindlin-2 was cloned into vector pGBKT7, and the integrin $\beta$ CTs were cloned into vector pGADT7. Self-activation of these constructs was evaluated and excluded. Protein-protein interaction was examined according to the manufacturer's protocol.

\section{Pull-down assays}

HUVECs transiently expressing EGFP- $\beta 3$-endonexin were lysed using CelLytic Cell Lysis Reagent (Sigma) in the presence of protease inhibitors (Roche). Purified GST and GST-fused integrin $\beta$ CT proteins were loaded on Glutathione Sepharose 4B beads (GE Healthcare) and incubated with the lysates of HUVECs for overnight in a $4{ }^{\circ} \mathrm{C}$ cold room in the presence or absence of the indicated $\mathrm{m} \beta \mathrm{CTP}$. After washing, EGFP- $\beta 3$-endonexin and endogenous kindlin-2 in the precipitates were analyzed by Western blotting. GST proteins loaded on the beads were evaluated by Coomassie blue staining.

\section{Knockdown of endogenous $\beta 3$-endonexin in HUVECs}

An siRNA duplex specifically targeting $\beta 3$-endonexin was used to knocking down endogenous $\beta 3$-endonexin (RiboBio). The sequence targeting $\beta 3$-endonexin was GAACTTGTCAAATGAGTCT. A non-targeting control siRNA duplex was used as a control. After transfecting HUVECs with siRNA duplexes for $48 \mathrm{~h}$, cells were harvested for functional analysis. Meanwhile, the expressing levels of endogenous $\beta 3$-endonexin were evaluated by quantitative RT-PCR.

\section{Quantitative RT-PCR (qRT-PCR)}

Total RNA was extracted from HUVECs using a TRIzol kit (Invitrogen). A PrimeScript ${ }^{\circ}$ RT reagent Kit (Takara) was used for cDNA synthesis. For quantitative analysis of the mRNA levels of the tested genes, the synthesized cDNA was used as a template and subjected to 40 cycles of quantitative PCR using Takara SYBR Premix Ex Taq ${ }^{\mathrm{mm}}$ in the CFX96 ${ }^{\text {TM }}$ Real-Time PCR Detection System (Bio-Rad). Primer sequences (forward and reverse) used in this study were as follows: 33 -endonexin forward, 5'-TCACTGAAGTTGGATGGTCTGT-3', and reverse, 5'AGTCCATTTCTGTGCTTTTGCT-3'; VEGFA forward, 5'-AGGGCAGAATCATCACGAAGT-3', and reverse, 5'-AGGGTCTCGATTGGATGGCA-3'; $\beta$-actin forward, 5'-TCCATCATGAAGTGTGACGT-3', and reverse, 5' - AGGAGGAGCAATGATCTTGA-3'. For each independent experiment, samples were loaded in triplicate, and the value of each sample was normalized by $\beta$-actin.

\section{Results}

The $m \beta C T P s$ selectively inhibit HUVEC tube formation The C-termini of the integrin $\beta$ CTs (except for $\beta 4$ and $\beta 8$ ) contain a conserved NxxY/F motif and an S/T cluster region (Fig. 1a), which are important docking regions for cytoplasmic binding partners, such as kindlins and $\beta 3$-endonexin. Since it has been reported that kindlins and $\beta 3$-endonexin are both involved in regulating angiogenesis, we sought to evaluate the antiangiogenic capacity of the C-terminal region of the $\beta$ CTs. As shown in Fig. 1a, the C-terminal regions of the $\beta$ CTs comprising the NxxY/F motif and the S/T cluster ( $\beta C T P$ ) were selected and fused with a cell penetrating TAT amino-acid sequence $[29,30]$, thus to constitute membrane-permeable peptides (termed as $\mathrm{m} \beta \mathrm{CTP}$ ) (also see Additional file 1: Figure S1). HUVEC tube formation assays were performed to functionally analyze angiogenesis in vitro. HUVECs were seeded on polymerized Matrigel to induce the formation of capillary-like tube structures. As shown in Fig. 1b, c, treating HUVECs with $\mathrm{m} \beta 3 \mathrm{CTP}$, 


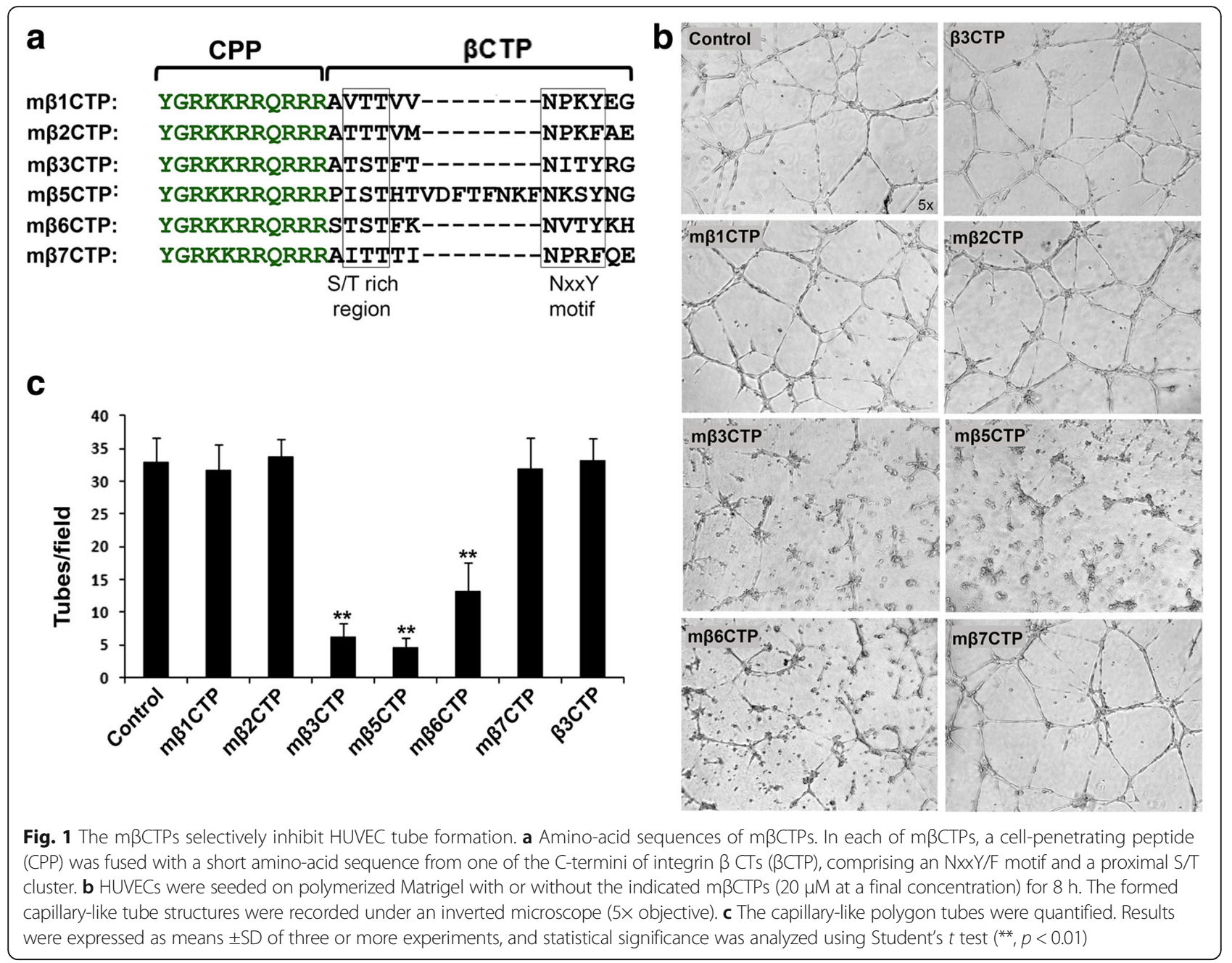

$\mathrm{m} \beta 5 \mathrm{CTP}$ and $\mathrm{m} \beta 6 \mathrm{CTP}$ substantially impaired HUVEC tube formation. However, the other $\mathrm{m} \beta \mathrm{CTPs}$, including $\mathrm{m} \beta 1 \mathrm{CTP}, \mathrm{m} \beta 2 \mathrm{CTP}$ and $\mathrm{m} \beta 7 \mathrm{CTP}$, had no effect on inhibiting HUVEC tube formation. As a control, $\beta 3$ CTP lacking the cell penetrating ability failed to inhibit HUVEC tube formation (Fig. $1 \mathrm{~b}$ and Additional file 1: Figure S1b). Together, these results suggest that different $\mathrm{m} \beta \mathrm{CTPs}$ have distinct antiangiogenic ability.

\section{The $m \beta C T P s$ selectively inhibit angiogenesis in subcutaneous Matrigel plugs}

We next employed the in vivo Matrigel plug assay to evaluate the antiangiogenic ability of the m $\beta$ CTPs. Liquid Matrigel can be quickly solidified to form a plug after subcutaneous injection in mice. As shown in Fig. 2a, the implanted Matrigel plug could effectively trigger angiogenesis to form visible blood vessels (see control). Histological analysis by H\&E staining revealed that the newly formed vessels were randomly distributed in implanted Matrigel plugs (Fig. 2b, control). Due to the significant variation of the sizes of formed vessels, we decided to evaluate the vascularization by quantifying hemoglobin contained in the Matrigel plugs (Fig. 2c). We found that three $\mathrm{m} \beta \mathrm{CTPs}(\mathrm{m} \beta 3 \mathrm{CTP}, \mathrm{m} \beta 5 \mathrm{CTP}$ and $\mathrm{m} \beta 6 \mathrm{CTP}$ ) that could suppress HUVEC tube formation in vitro could also inhibit blood vessel formation in Matrigel plugs in vivo, although m $\beta 6 C T P$ was less effective. However, the formation of blood vessels and the amount of hemoglobin in Matrigel plugs after treatment with $\mathrm{m} \beta 1 \mathrm{CTP}, \mathrm{m} \beta 2 \mathrm{CTP}$ and $\mathrm{m} \beta 7 \mathrm{CTP}$ were similar with the non-treated control. These results further verify the distinct roles of different $\mathrm{m} \beta \mathrm{CTPs}$ in regulating angiogenesis.

The antiangiogenic $m \beta C T P s$ suppress solid tumor growth Angiogenesis plays an essential role for supporting in vivo solid tumor growth. Therefore, we tested if the antiangiogenic $\mathrm{m} \beta C$ TPs identified above have antitumor capacity. RM1 prostate tumor cells were subcutaneously injected into BALB/c nude mice and allowed to grow to solid tumors. When the size of tumors reached to $\sim 200 \mathrm{~mm}^{3}$ (around day 5 after inoculation), tumor-bearing mice were 
a

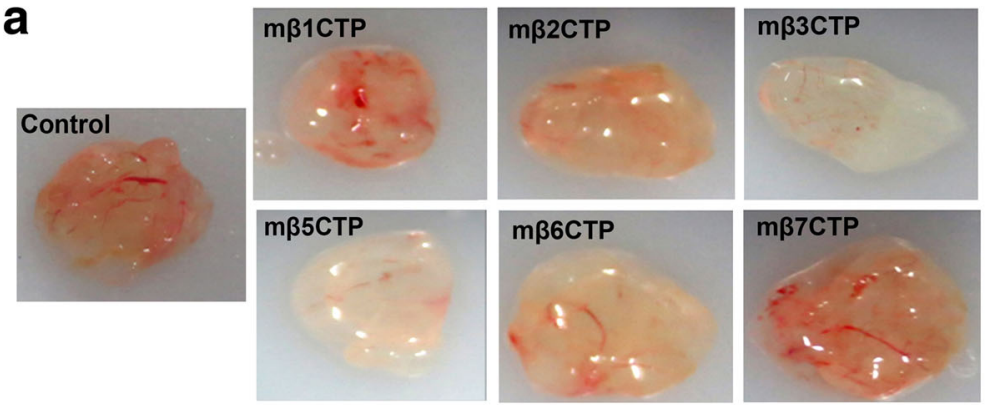

b

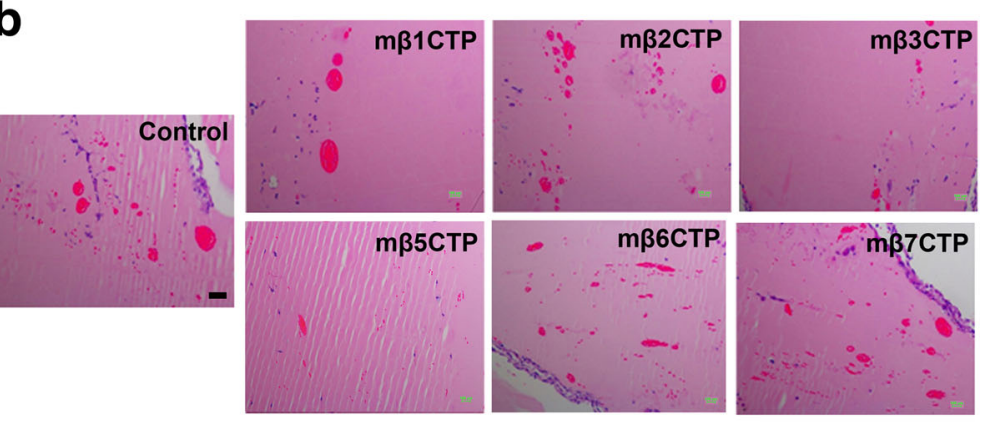

C

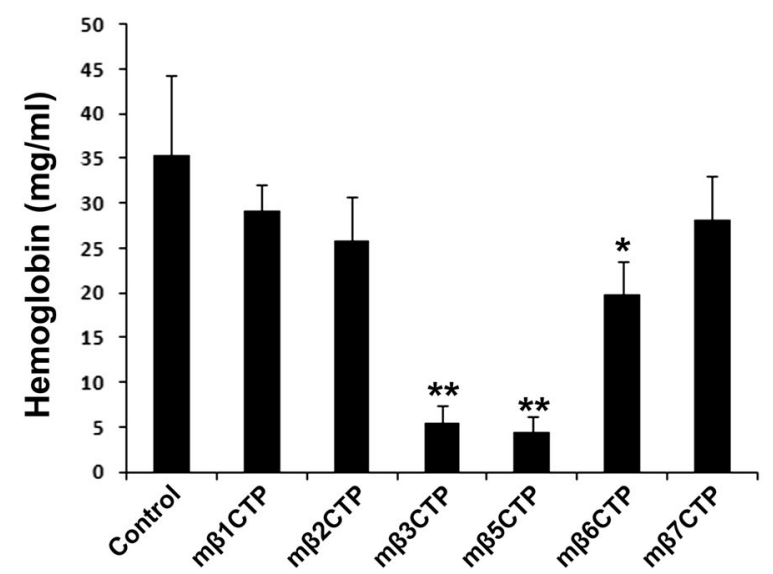

Fig. 2 The $m \beta C T P s$ selectively suppress blood vessel formation in implanted Matrigel plugs. a Aliquots of Matrigel liquid supplemented with the indicated mBCTPs (50 $\mu \mathrm{M}$ at a final concentration) were subcutaneously injected into BALB/c nude mice $(n=5)$ to form solid Matrigel plugs. Matrigel that did not contain peptides was used as a control. After 7 days, Matrigel plugs were carefully isolated and photographed. b Matrigel plugs were fixed and paraffin-embedded for histological analysis. Representative H\&E staining images of the Matrigel plug sections were shown. Scale bar, $200 \mu \mathrm{m}$. c The amount of hemoglobin in Matrigel plugs was quantified by Drakin's reagent. Results were expressed as means \pm SD of five samples; statistical significance was analyzed using Student's $t$ test $\left({ }^{*}, p<0.05 ;{ }^{* *}, p<0.01\right)$

locally treated with the antiangiogenic m $\beta C T P s$. Compared to a sham treatment in control mice, tumor growth was significantly reduced in mice treated with either m 33 CTP or m 35 CTP (Fig. 3a and Additional file 1: Figure S3). However, under the same experimental conditions, treatment with $\mathrm{m} \beta 6 \mathrm{CTP}$ failed to suppress tumor growth, which may be due to its weaker antiangiogenic ability (Fig. 2). These results demonstrate that these three antiangiogenic $\mathrm{m} \beta \mathrm{CTPs}(\mathrm{m} \beta 3 \mathrm{CTP}, \mathrm{m} \beta 5 \mathrm{CTP}$ and $\mathrm{m} \beta 6 \mathrm{CTP})$ have different antitumor capacity.

To explore if the antitumor function of $\mathrm{m} \beta 3 \mathrm{CTP}$ and $\mathrm{m} \beta 5 \mathrm{CTP}$ correlates with their antiangiogenic property, the formed blood vessels in tumor tissues were analyzed by histological staining of CD31, a marker of vascular endothelial cells. As shown in Fig. 3b, c, after treatment with $\mathrm{m} \beta 3 \mathrm{CTP}$ or $\mathrm{m} \beta 5 \mathrm{CTP}$, the blood vessel numbers in tumors were significantly less than those in control tumors with sham treatment, demonstrating that the antitumor property of $\mathrm{m} \beta 3 \mathrm{CTP}$ and $\mathrm{m} \beta 5 \mathrm{CTP}$ can be ascribed to their antiangiogenic ability. To test if the antiangiogenic peptides also inhibit tumor cell proliferation, we treated the RM1 prostate tumor cells with either $\mathrm{m} \beta 3 \mathrm{CTP}$ or $\mathrm{m}$ 35CTP under culture conditions and found that neither had significant effect at the experimental conditions 

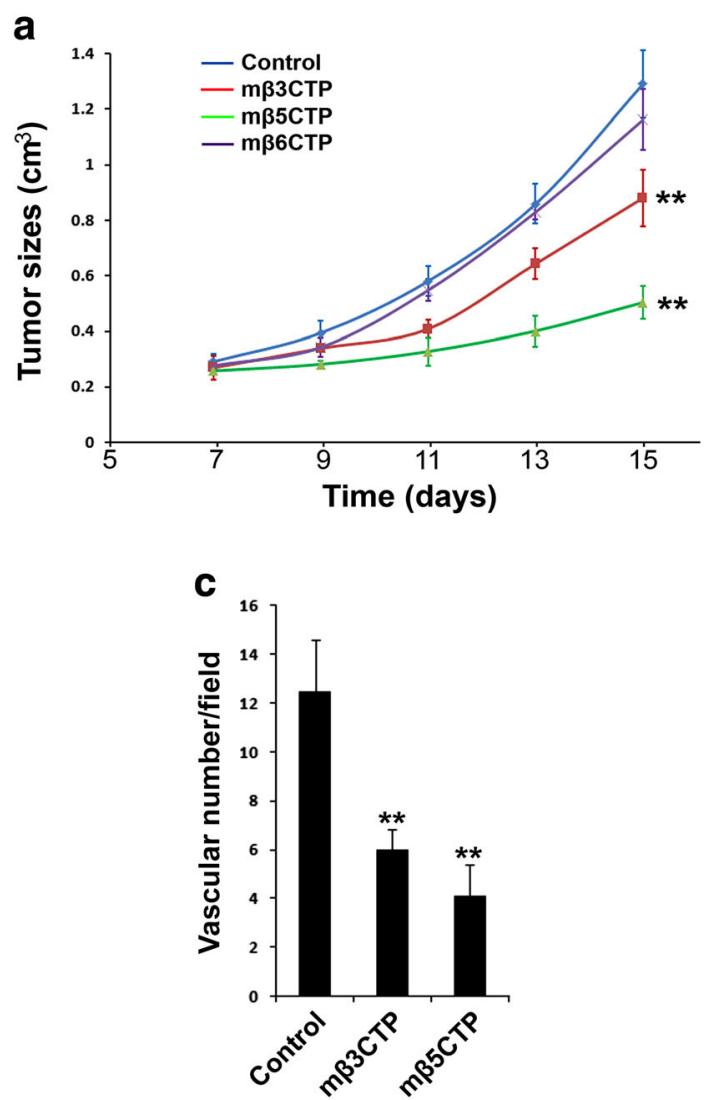
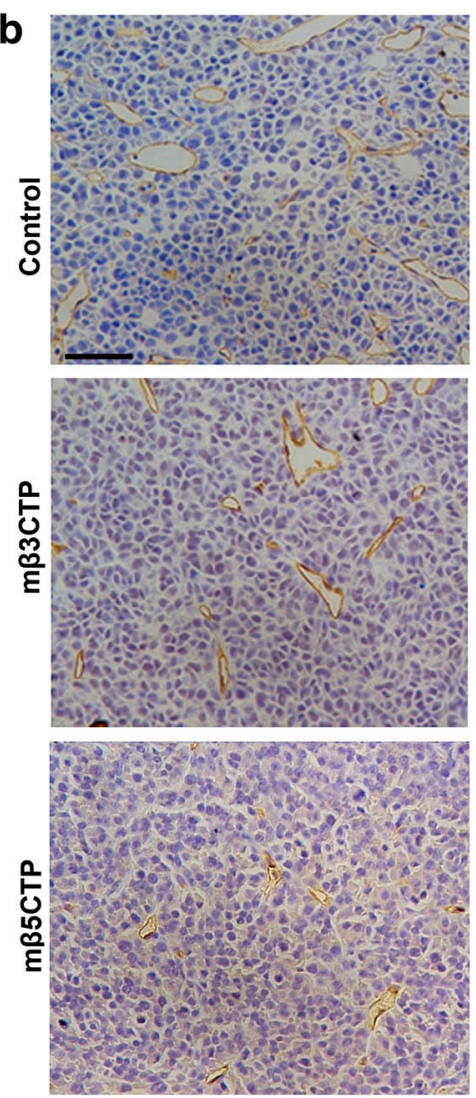

Fig. 3 The antiangiogenic m $\beta C$ TPs show antitumor activity. a $1.2 \times 10^{6}$ of RM1 cancer cells were subcutaneously injected into BALB/c nude mice $(n=6)$. Starting on day 5 , the formed tumor areas were subjected to treatment by local injection of $100 \mu$ of the indicated $m \beta C T P$ solution $(50 \mu M$ at a final concentration) every other day. PBS alone was used as a control. Length (I) and width ( $W$ ) of the formed tumors were measured, and tumor volumes (v) were calculated by using the following formula: $v=0.52\left(\mid \times w^{2}\right)$. b, $\mathbf{c}$ The tumor tissues were harvested on day 15 and subjected to $I H C$ staining for CD31, a marker of vascular endothelial cells. Blood vessels in solid tumor tissues were quantified. Scale bar, $50 \mu \mathrm{m}$. The results were expressed as means \pm SD; statistical significance was analyzed using Student's $t$ test $(* *, p<0.01)$

(Additional file 1: Figure S2). Collectively, these results suggest that $\mathrm{m} \beta 3 \mathrm{CTP}$ and $\mathrm{m} \beta 5 \mathrm{CTP}$ may suppress in vivo solid tumor growth via their antiangiogenic function.

\section{The antiangiogenic $m \beta C T P$ s do not affect HUVEC adhesion and migration under stimulations}

Since these antiangiogenic $m \beta C$ TPs are integrin $\beta$ CT based peptides, we next sought to evaluate if they affect integrin (especially $\alpha v \beta 3$ ) mediated HUVEC adhesion and migration on fibrinogen. Under the same dose as used in the HUVEC tube formation assay, we detected that m $\beta 3$ CTP could moderately suppress HUVEC adhesion to immobilized fibrinogen in the absence stimulation while m $\beta 5$ CTP had no effect (Fig. 4a). However, m $\beta 1 C T P$, one of the non-antiangiogenic m $\beta C T P s$, also inhibited HUVEC adhesion under the same condition. Interestingly, none of the m $\beta C T P s$ affects VEGF-stimulated HUVEC adhesion (Fig. 4a). In addition, we found that all the $\mathrm{m} \beta C$ TPs failed to affect VEGF-induced HUVEC migration on fibrinogen (Fig. 4b, c). We also performed these assays on vitronectin and obtained the similar results (Additional file 1: Figure S4). Since HUVECs poorly migrated in the absence of stimulation (results not shown), we did not evaluate the effect of $\mathrm{m} \beta C$ TPs on HUVEC migration under non-stimulated conditions. Together, these results show that the antiangiogenic ability of the $\mathrm{m} \beta \mathrm{CTPs}$ is not consistent with their capacity to affect integrin activity, indicating that the antiangiogenic $\mathrm{m} \beta C$ TPs may employ integrin-independent mechanisms to modulate angiogenesis.

\section{Identification of the antiangiogenic core in $\mathrm{m} \beta 3 \mathrm{CTP}$}

Next, we attempted to map the antiangiogenic core region in $\mathrm{m} \beta 3 \mathrm{CTP}$. To do so, a series of truncated $\mathrm{m} \beta 3 \mathrm{CTP}$ variants with sequential deletions from either side of the $\beta 3$ CTP were prepared (Fig. 5a). Then the antiangiogenic ability of each of them was tested using the HUVEC tube formation assay. As shown in Fig. 5b, c, deletion of the $\mathrm{C}$-terminal RG residues in $\mathrm{m} \beta 3 \mathrm{CTP}$ did not affect the antiangiogenic efficacy; however, deletion of the 


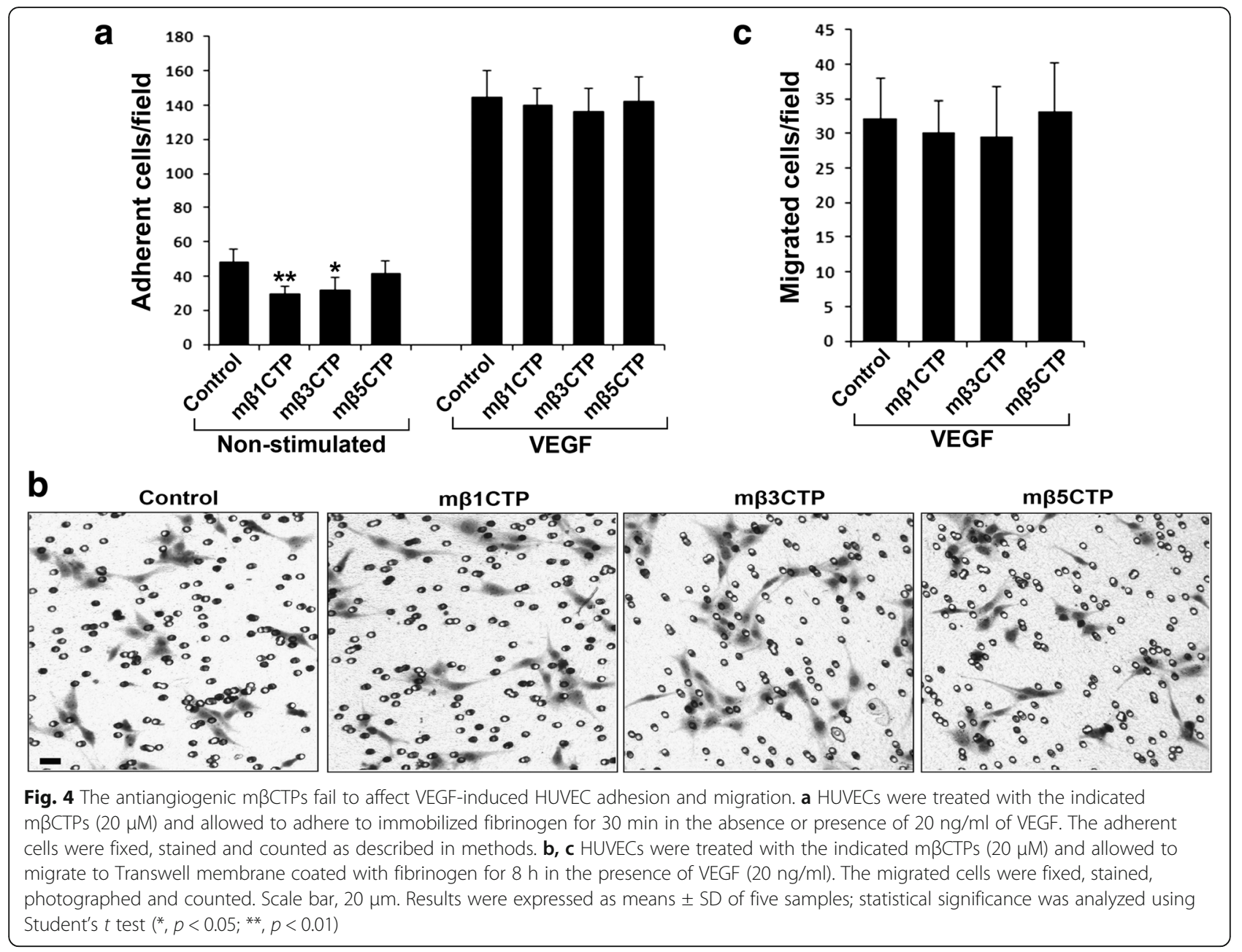

C-terminal YRG residues that includes tyrosine in the NITY motif abrogated the antiangiogenic ability, indicating that the NITY motif is required for the antiangiogenic function. In addition, $\mathrm{m} \beta 3 \mathrm{CTP}$ missing the $\mathrm{N}$-terminal TST region showed a significantly compromised antiangiogenic ability, suggesting that the conserved S/T cluster in $\mathrm{m} \beta 3 \mathrm{CTP}$ is also involved in supporting antiangiogenesis. Particularly, $\mathrm{m} \beta 3 \mathrm{CTP}$ with deletion of one more residue after the TST cluster totally lost the antiangiogenic ability, implying that the N-terminally flanking residues of the NITY motif also participate in antiangiogenesis. Together, these results suggest that the $\mathrm{xNITY}$ motif (here $\mathrm{x}$ represents two or more residues) in $\mathrm{m} \beta 3 \mathrm{CTP}$ is primarily responsible for the antiangiogenic function.

Since the residue tyrosine in the NITY motif of the $\beta 3$ CT is a phosphorylation site [31,32], we next evaluated the potential effect of tyrosine phosphorylation on the antiangiogenic ability of $\mathrm{m} \beta 3 \mathrm{CTP}$. As shown in Fig. $5 \mathrm{a}$, a structurally conserved $\mathrm{Y} / \mathrm{F}$ mutation was introduced into m $\beta 3$ CTP to prevent tyrosine phosphorylation. Notably, the $\mathrm{m} \beta 3 \mathrm{CTP}$ variant carrying the $\mathrm{Y} / \mathrm{F}$ mutation still sufficiently inhibited HUVEC tube formation as shown in
Fig. 5b, c, demonstrating that tyrosine phosphorylation in the NITY motif is not required for $\mathrm{m} \beta 3 \mathrm{CTP}$ to suppress angiogenesis. In addition, we employed a modified $\mathrm{m} \beta 3 \mathrm{CTP}$ with a phosphorylated tyrosine and found that such a tyrosine phosphorylated peptide showed a significantly reduced ability in inhibiting HUVEC tube formation (data not shown). Together, these results indicate that tyrosine phosphorylation in $\mathrm{m} \beta 3 \mathrm{CTP}$ is not required for antiangiogenesis.

\section{The integrin $\beta$ CTs and the derived $m \beta C T P s$ selectively interact with $\beta 3$-endonexin}

Multiple binding partners have been identified for the C-terminal NITY motif in the integrin $\beta 3 \mathrm{CT}$ (details in the section of Discussion). Among them, $\beta 3$-endonexin is specific for the $\beta 3 \mathrm{CT}$ because it does not bind the $\beta 1$ and $\beta 2$ CTs $[21,22]$. As summarized in Table 1 , the NITY motif in the $\beta 3 \mathrm{CT}$ is essentially required for interacting with $\beta 3$-endonexin. Interestingly, the N-terminal residues beyond the NITY motif also participate in the interaction, which is compatible with the antiangiogenic core $(x N I T Y)$ identified in $\mathrm{m} \beta 3 \mathrm{CTP}$. 
a
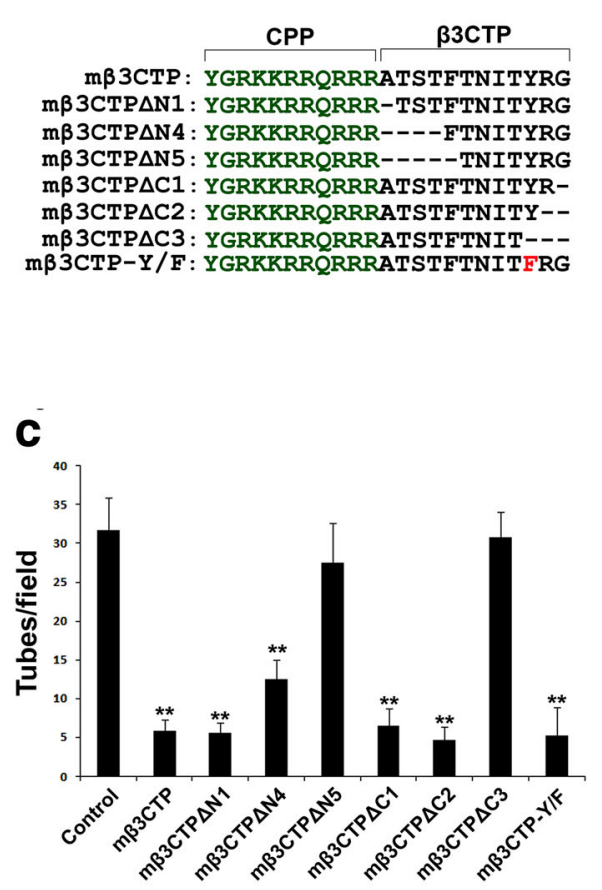

b

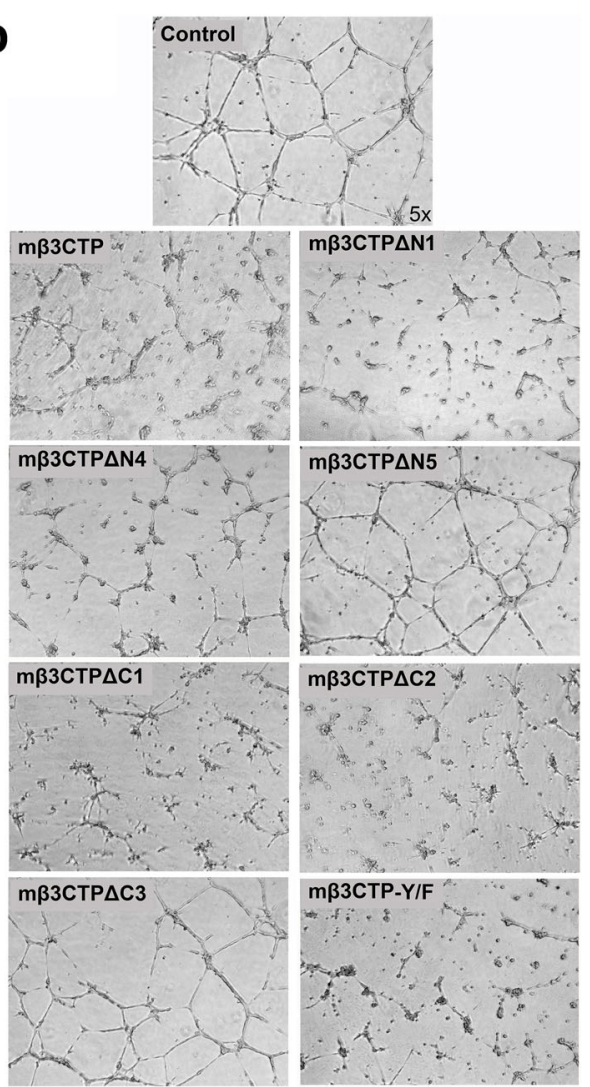

Fig. 5 Identify the antiangiogenic core region in m $\beta 3 C T P$. a The amino-acid sequences of different $m \beta 3 C T P$ variants with sequential residue deletions from either side of $\beta 3$ CTP were shown. $\mathbf{b}, \mathbf{c}$ HUVECs were seeded on polymerized Matrigel in 24-well plates and treated with the indicated m $\mathrm{B} 3 \mathrm{CTP}$ variants ( $20 \mu \mathrm{M}$ at a final concentration) or PBS alone as a control. The formed capillary-like structures were counted under an inverted microscope ( $5 \times$ objective). Results were expressed as means $\pm S D$ from three experiments; statistical significance was analyzed using Student's $t$ test $(* *, p<0.01)$

Therefore, we hypothesize that $\beta 3$-endonexin may serve as a functional effector for the antiangiogenic m $\beta$ CTPs. To demonstrate this hypothesis, we first performed a pull-down experiment, in which the lysates of HUVECs expressing of EGFP- $\beta 3$-endonexin were used to incubate with GST-fused integrin $\beta$ CTs in the presence of glutathione-Sepharose beads. As shown in Fig. 6a, we found that EGFP- $\beta 3$-endonexin was able to interact with both the $\beta 3$ and $\beta 5$ CTs. A relatively weak interaction between EGFP- $\beta 3$-endonexin and the $\beta 6 \mathrm{CT}$ was also detected. However, the signal of interaction between EGFP- $\beta 3$-endonexin and the $\beta 1, \beta 2$ or $\beta 7 \mathrm{CT}$ was close to the background. Interestingly, endogenous kindlin- 2 was found to be able to bind the $\beta 1, \beta 3$ and $\beta 7 \mathrm{CTs}$ but not others, showing that kindlin-2 and $\beta 3$-endonexin have distinct binding patterns to the integrin $\beta$ CTs.

Further, we employed the yeast 2-hybrid system to verify the interaction. As shown in Fig. $6 \mathrm{~b}$, both the integrin $\beta 3$ and $\beta 5$ CTs showed a significant binding signal to $\beta 3$-endonexin; the integrin $\beta 6 \mathrm{CT}$ exhibited a weak but detectable interaction with $\beta 3$-endonexin; however, the interaction of $\beta 3$-endonexin with the $\beta 1$, $\beta 2$ and $\beta 7$ CTs was undetectable. Meanwhile, kindlin-2 was found to interact with the $\beta 1, \beta 3$ and $\beta 7$ CTs but not with the other $\beta$ CTs under the experiment conditions. These results are consistent with the observation from the pull down assays (Fig. 6a). In the yeast two-hybrid assay, empty vectors and a pair of known binding molecules (Bop1/Bop2) were used as negative and positive controls, respectively. Together, these results suggest that the capacity of $\beta 3$-endonexin binding may correlate with the antiangiogenic function of m $\beta$ CTPs. Thus, we further tested if the peptides of $\beta 3 \mathrm{CTP}$ and $\beta 5 \mathrm{CTP}$ can directly bind $\beta 3$-endonexin. In the yeast 2 -hybrid assay, we found that $\beta 3$-endonexin did interact with $\beta 5 \mathrm{CTP}$. However, the interacting signal between $\beta 3$-endonexin and $\beta 3$ CTP was substantially weak (Fig. $6 \mathrm{c}$ ), which is consistent with the finding that $\mathrm{m} \beta 5 \mathrm{CTP}$ is more effective than $\mathrm{m} \beta 3 \mathrm{CTP}$ in 
Table 1 Summary of the yeast two-hybrid results from previous publications [21, 22]

\begin{tabular}{|c|c|c|}
\hline Name & Amino-acid sequence & $\beta 3$-EN binding \\
\hline$\overline{\beta 1 C T:}$ & -KLLMIIHDRREFAKFEKEKMNAKWDTGENPIYKSAVTTWNPKYEGK & $-(a)$ \\
\hline$\beta 2 C \mathrm{~T}:$ & -KALIHLSDLREYRRFEKEKLKSQWN-NDNPLFKSATTTVMNPKFAES & - \\
\hline$\beta 3 С$ & -KLLITIHDRKEFAKFEEERARAKWDTANNPLYKEATSTFTNITYRGT ${ }^{(c)}$ & + \\
\hline$\beta 3 C T-\Delta 762:$ & -KLLITIHDRKEFAKFEEERARAKWDTANNPLYKEATSTFTNITYRG & + \\
\hline$\beta 3 C T-\Delta 761:$ & -KLLITIHDRKEFAKFEEERARAKWDTANNPLYKEATSTFTNITYR & + \\
\hline$\beta 3 C T-\triangle 760:$ & -KLLITIHDRKEFAKFEEERARAKWDTANNPLYKEATSTFTNITY & + \\
\hline$\beta 3 C T-\triangle 759:$ & -KLLITIHDRKEFAKFEEERARAKWDTANNPLYKEATSTFTNIT & - \\
\hline$\beta 3 C T-\triangle 755:$ & -KLLITIHDRKEFAKFEEERARAKWDTANNPLYKEATSTF & - \\
\hline allb/ß3CT: & -KVGFFKRNRPPLEEDDEEGQNITYRGT & - \\
\hline$\beta 1 / \beta 3 C T 1:$ & -KLLMIIHDRREFAKFEKEKMNAKWDTGENPIYKSAVTTVNITYRGT & + \\
\hline$\beta 1 / \beta 3 С \mathrm{C} 2$ & -KLLMIIHDRREFAKFEKEKMNAKWDTGENPIYKSAVTTVNITYEGK & + \\
\hline$\beta 3 / \beta 1 C T 1:$ & -KLLITIHDRKEFAKFEEERARAKWDTANNPLYKEATSTFTNPKYEGK & - \\
\hline$\beta 3 / \beta 1 C T 2:$ & -KLLITIHDRKEFAKFEEERARAKWDTANNPLYKEATSTFTNPKYRGT & - \\
\hline$\beta 3 C T-1 / P:$ & -KLLITIHDRKEFAKFEEERARAKWDTANNPLYKEATSTFTNPTYRGT & - \\
\hline$\beta 3 C T-Y / F:$ & -KLLITIHDRKEFAKFEEERARAKWDTANNPLYKEATSTFTNITFRGT & + \\
\hline Binding core: & & $X \mathbf{N I T Y}(b)$ \\
\hline
\end{tabular}

(a) The interactions between $\beta 3$-endonexin ( $\beta 3-\mathrm{EN}$ ) and the original and chimeric integrin $\beta$ CTs were defined by arbitrary units (AU) of $\beta$-Galactosidase as described in the publications. (Positive interactions (+): $A U>5$; negative interactions $(-)$ : $A U<5$ )

(b) The " $x$ " represented undetermined amino acids (number and residues)

(c) Amino acids from the integrin $\beta 3 \mathrm{CT}$ were shown in boldface

antitumor (Fig. 3). Nonetheless, results from a competition experiment showed that either m $\beta 3 \mathrm{CTP}$ or $\mathrm{m} \beta 5 \mathrm{CTP}$ was able to inhibit the $\beta 3 \mathrm{CT}$ binding to $\beta 3$-endonexin (Fig. $6 \mathrm{~d}$ ), verifying that both $\beta 3 \mathrm{CTP}$ and $\beta 5$ CTP can interact with $\beta 3$-endonexin.

B3-Endonexin is required for HUVEC tube formation but not essential for integrin-mediated HUVEC adhesion and migration To test if $\beta 3$-endonexin in vascular endothelia cells plays a role in angiogenesis, we used a specific siRNA to knock down endogenous $\beta 3$-endonexin in HUVECs, and meanwhile used a non-targeting siRNA as a control. Transfection of HUVECs with the siRNA for $\beta 3$-endonexin significantly suppressed the expression of $\beta 3$-endonexin when compared with the control siRNA (Fig. 7a, b). Importantly, we found that HUVEC tube formation was significantly impaired when down-regulating endogenous $\beta 3$-endonexin (Fig. 7c, d). This result suggests that endogenous $\beta 3$-endonexin in vascular endothelial cells is required to support angiogenesis.

Since $\beta 3$-endonexin has been identified as a binding partner for the integrin $\beta 3 \mathrm{CT}$, we further tested if $\beta 3$-endonexin is involved in regulating $\alpha \mathrm{v} \beta 3$-mediated HUVEC adhesion and migration on fibrinogen. As shown in Fig. 7e-g, knockdown of endogenous $\beta 3$-endonexin neither affected HUVEC adhesion in the presence or absence of VEGF stimulation, nor altered VEGF-induced HUVEC migration. These results suggest that $\beta 3$-endonexin is dispensable for integrin-mediated HUVEC adhesion and migration, and also indicate that the proangiogenic role of $\beta 3$-endonexin may be through an integrin-independent mechanism.

Both the antiangiogenic $m \beta C T P s$ and $\beta 3$-endonexin are involved in regulating HUVEC proliferation and VEGF expression in HUVECs

To mechanistically understand the functional correlation between the antiangiogenic $\mathrm{m} \beta \mathrm{CTPs}$ and $\beta 3$-endonexin, we evaluated each of their influences on cell proliferation and VEGF expression in HUVECs, since it was reported that the $\beta 3$-endonexin family is involved in regulating both events $[24,33]$. We found that treatment of HUVECs with both $\mathrm{m} \beta 3 \mathrm{CTP}$ and $\mathrm{m} \beta 5 \mathrm{CTP}$, two antiangiogenic peptides, significantly suppressed HUVEC proliferation, as evaluated by the CCK-8 Cell Counting Kit (Fig. 8a) and the MTT assay (Additional file 1: Figure S5). However, treating HUVECs with $\mathrm{m} \beta 1 \mathrm{CTP}$, one of the non-antiangiogenic m $\beta C$ TPs, failed to affect cell proliferation. In addition, treatment with both $\mathrm{m} \beta 3 \mathrm{CTP}$ and $\mathrm{m} \beta 5 \mathrm{CTP}$ but not with $\mathrm{m} \beta 1 \mathrm{CTP}$ was found to suppress the expression of VEGF in HUVECs (Fig. 8c). Consistently, knocking down endogenous $\beta 3$-endonexin in HUVECs by siRNA was able to inhibit both cell proliferation and VEGF expression (Fig. 8b, d). Importantly, we found that addition of VEGF could alleviate the suppression of HUVEC tube formation by the antiangiogenic $\mathrm{m} \beta C$ TPs or siRNA against $\beta 3$-endonexin (Fig. 8e, f), suggesting that the antiangiogenic effect of 

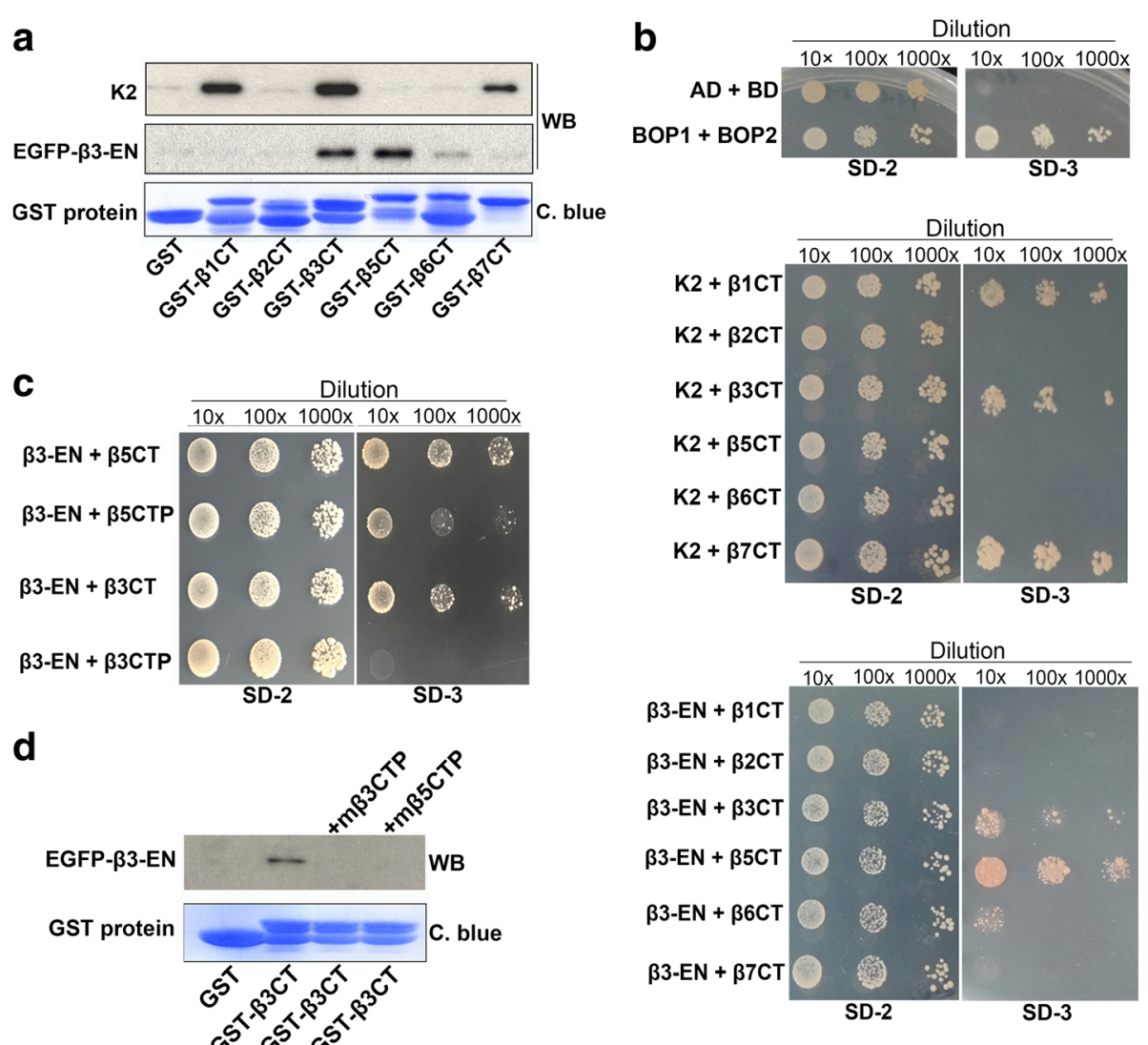

Fig. 6 The antiangiogenic m $\beta C T P s$ specifically interact with $\beta 3$-endonexin. a Lysate aliquots of HUVECs exogenously expressing EGFP- $\beta 3$-endonexin (EGFP- $\beta 3$-EN) were incubated with purified GST or GST-fused $\beta$ CT proteins coupled on Glutathione Sepharose beads. After incubation, the beads were washed and the precipitated proteins were separated by SDS-PAGE. The loaded GST proteins on the beads were assessed by Coomassie blue (C. blue) staining. The co-precipitated EGFP- $\beta 3$-endonexin and endogenous kindlin-2 (K2) were detected by Western blotting. $\mathbf{b}$ Interaction of the $\beta$ CTs with $\beta 3-E N$ or K2 was evaluated using the yeast 2-hybrid system by a serial dilution method on selection media. Two known interacting molecules (Bop1 and Bop2) were employed here as a positive control, and empty vectors were transformed to serve as a negative control. The growth of yeast cells on SD-2 media (-Leu/-Trp) indicates a successful transformation; the growth on SD-3 selection media (-Leu/-Trp/-His) indicates a positive protein-protein interaction. $\mathbf{c}$ The interaction of $\beta 3$-EN with $\beta 3$ CTP and $\beta 5 C T P$ was evaluated using the yeast 2-hybrid system. $\mathbf{d}$ Interaction between EGFP- $\beta 3$-endonexin

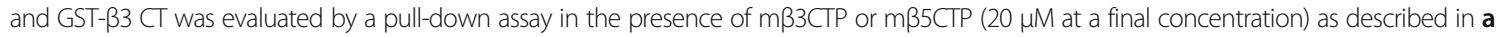

$\mathrm{m} \beta \mathrm{CTPs}$ or siRNA against $\beta 3$-endonexin may be due to their suppression on VEGF expression, at least partially. Taken all together, these results suggest that the antiangiogenic $\mathrm{m} \beta C$ TPs may directly bind to $\beta 3$-endonexin and sequester its function in promoting VEGF expression in endothelial cells.

\section{Discussion}

Integrins have become the attractive targets for developing antiangiogenic strategies to treat solid tumors for many years. Specifically, the expression of $\alpha v \beta 3$ is significantly up-regulated in new born vessels, which makes $\alpha v \beta 3$ an ideal antiangiogenic target $[6,34]$. Importantly, preclinical studies have shown that some integrin $\alpha v \beta 3$ antagonists targeting the extracellular ligand binding exhibit promising antiangiogenic effects [35]. Nonetheless, the antiangiogenic potential of the integrin CTs has not been well evaluated. Previously, we have observed that kindlin-2, one of the integrin $\beta$ $\mathrm{CT}$ binding proteins and a key integrin activator, is required to support integrin $\alpha \mathrm{v} \beta 3$-mediated endothelial cell adhesion, migration and angiogenesis $[20,26]$. In addition, we have identified a core region in the integrin $\beta 1$ and $\beta 3$ CTs for binding to kindlin-2, a 12 amino-acid sequence $(\beta C T P)[25,36]$. Based on these finding, we designed a panel of membrane-permeable peptides (m $\beta C T P s)$ by conjugating each one of the $\beta C$ TPs with a cell penetrating peptide and tested their antiangiogenic function. Interestingly, we find that $\mathrm{m} \beta 3 \mathrm{CTP}$ and $\mathrm{m} \beta 5 \mathrm{CTP}$ can inhibit angiogenesis using both in vitro and in vivo models while m 36 CTP exhibits a moderate antiangiogenic capacity. However, the other m $\beta C$ TPs, including $\mathrm{m} \beta 1 \mathrm{CTP}, \mathrm{m} \beta 2 \mathrm{CTP}$ and $\mathrm{m} \beta 7 \mathrm{CTP}$, do not show significant antiangiogenic ability. Therefore, the antiangiogenic ability of the m $\beta$ CTPs is not consistent with the binding repertoire between the 


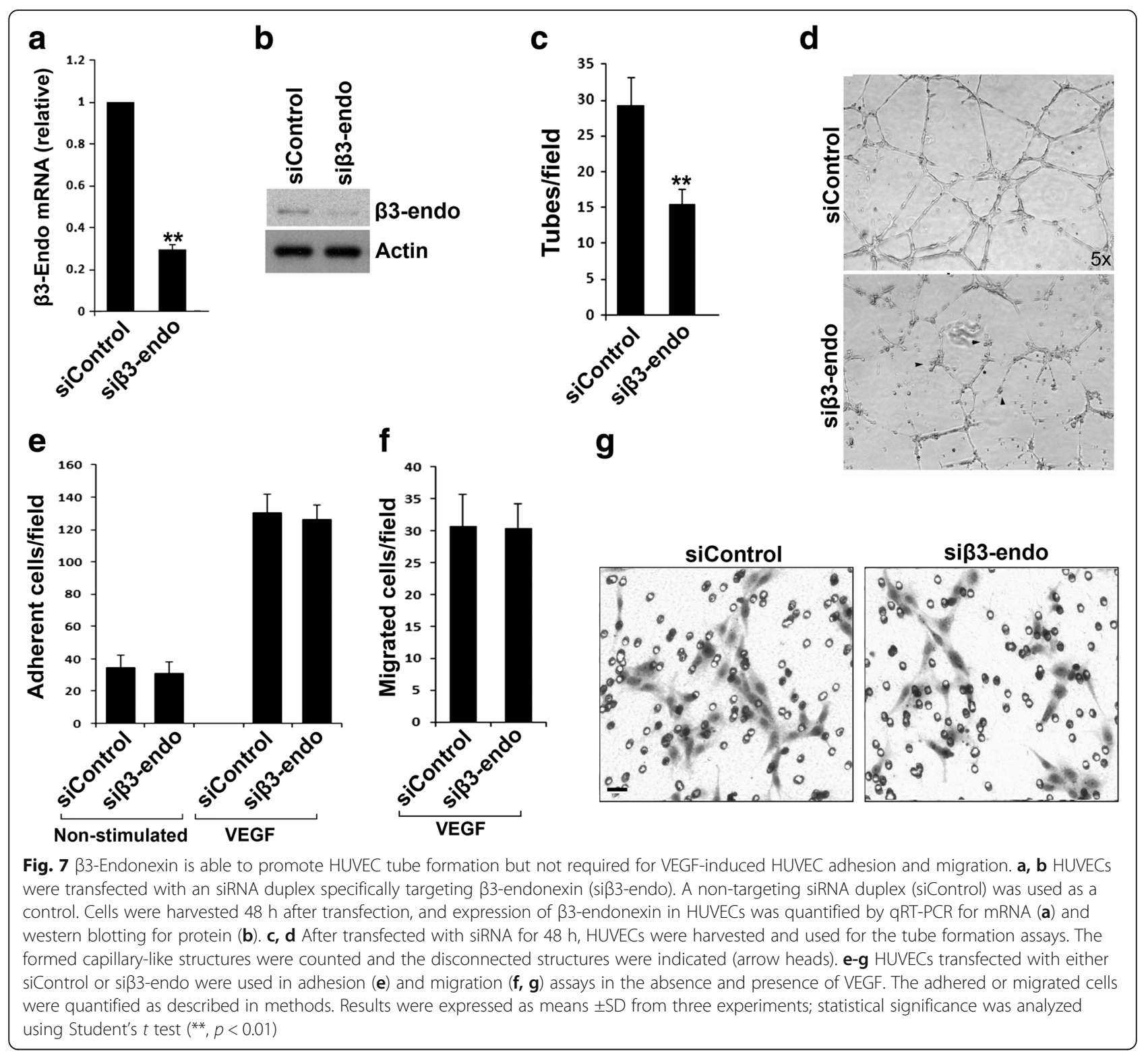

corresponding $\beta C$ Ts and kindlin-2. Further mapping the antiangiogenic core in $\mathrm{m} \beta 3 \mathrm{CTP}$ discloses that the C-terminal RGT residues in the $\beta 3 \mathrm{CT}$ are not essential, although these residues (RGT) are critically required for $\beta 3 \mathrm{CT}$ binding to kindlin-2 [37]. Hence, we conclude that the antiangiogenic function of $\mathrm{m} \beta \mathrm{CTPs}$ is independent of their binding to kindlin-2.

In addition to kindlin-2, a few of other proteins have been found to be able to interact with the NITY motif in integrin $33 \mathrm{CT}$, such as Shc [38], Grb2 [32], myosin [39], Src [40-42] and $\beta 3$-endonexin [21, 22]. While binding of the $\beta 3 \mathrm{CT}$ to Shc, Grb2 and myosin requires tyrosine phosphorylation of the NITY motif, interaction of $\beta 3$ $\mathrm{CT}$ with 33 -endonexin and $\mathrm{Src}$ is independent of tyrosine phosphorylation [22, 42]. Interestingly, both $\beta 3$-endonexin and Src can selectively bind the $\beta 3 \mathrm{CT}$, but not the $\beta 1$ and $\beta 2$ CTs, which is in line with the antiangiogenic feature of $\mathrm{m} \beta \mathrm{CTP}$. However, the antiangiogenic core identified in $\mathrm{m} \beta 3 \mathrm{CTP}$ is only compatible with the $\beta 3$-endonexin binding site in the $\beta 3$ CT [41], highlighting that $\beta 3$-endonexin, but not Src and others, may serve as an effector for the antiangiogenic m $\beta$ CTPs.

$\beta 3$-Endonexin, a 111 amino-acid polypeptide, has been found to be expressed in vascular endothelial cells [24, 27]. Interestingly, its expression has been found to be significantly up-regulated in post-chemotherapeutic lung cancer tissues [43], indicating that $\beta 3$-endonexin might be involved in regulating angiogenesis. In our study, we demonstrate that $\beta 3$-endonexin is proangiogenic and able to support HUVEC proliferation, tube formation 

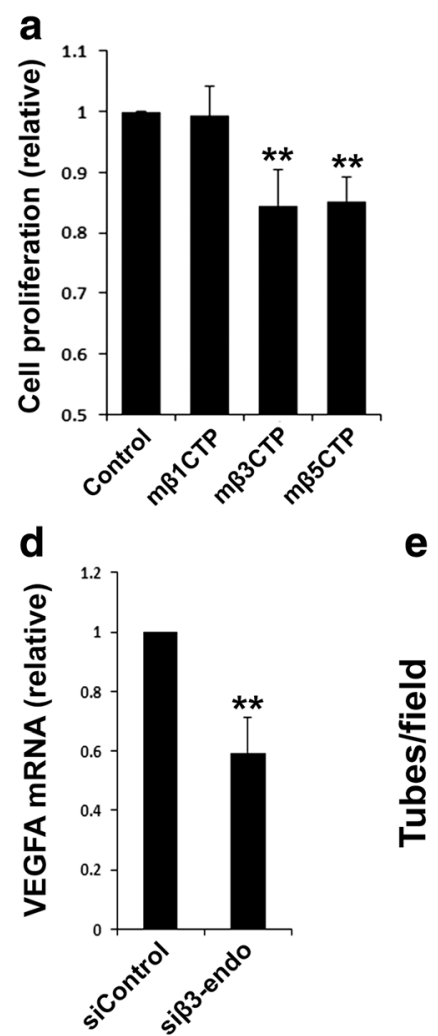

b

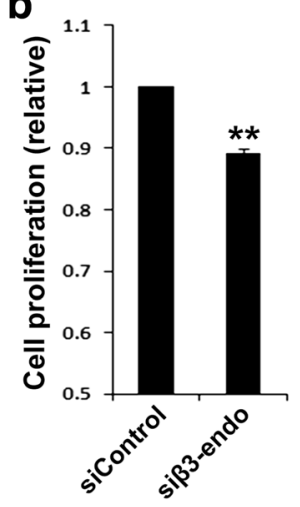

e

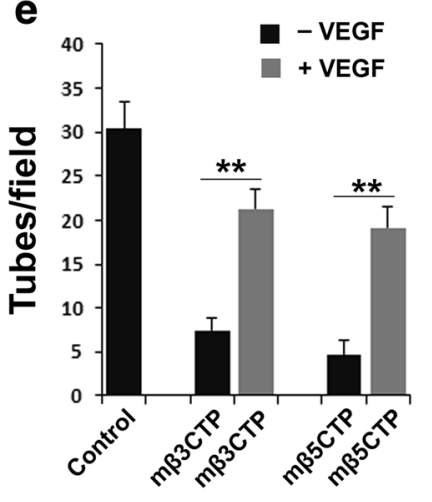

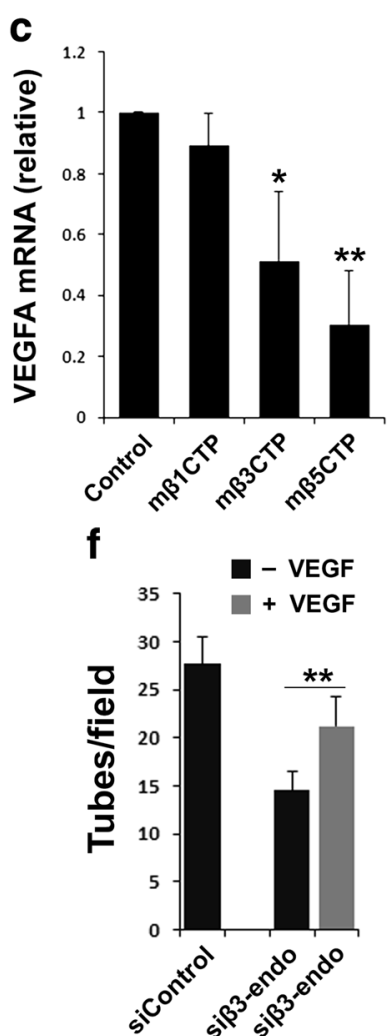

Fig. 8 Treatment with the antiangiogenic mßCTPs and knockdown of endogenous $\beta 3$-endonexin in HUVECs both suppress cell proliferation and VEGFA expression. HUVECs were treated with the indicated mBCTPs (20 $\mu \mathrm{M}$ at a final concentration) or transfected with siRNA (siControl or siß3-endo). a, $\mathbf{b}$ HUVEC proliferation was evaluated using CCK-8 cell proliferation assay. $\mathbf{c}$, $\mathbf{d}$ The expression levels of VEGFA mRNA in HUVECs were quantified by qRT-PCR. e, $\mathbf{f}$ HUVECs were treated with either siRNAs or m $\beta C T P s$ as indicated and seeded on polymerized Matrigel in 24-well plates in the absence or presence of VEGF $(20 \mathrm{ng} / \mathrm{ml})$. The formed capillary-like structures were counted under an inverted microscope (5× objective). Results were expressed as means \pm SD of three experiments; statistical significance was analyzed using Student's $t$ test $\left(^{*}, p<0.05 ;{ }^{* *}, p<0.01\right)$

and VEGF expression. However, a previous study reported that under hypoxic conditions $\beta 3$-endonexin acted as an antiangiogenic factor [24]. The molecular mechanism underlying this discrepancy is not clear, but it might be owing to the different experimental conditions used in these two studies (normoxia vs. hypoxia). As a transcriptional cofactor, the regulation of $\beta 3$-endonexin on target genes might be different under normoxia and hypoxia. Further studies, especially profiling the target genes of $\beta 3$-endonexin under these conditions, should be helpful to delineate the mechanisms.

Since $\beta 3$-endonexin is dispensable in integrin-mediated endothelial cell adhesion and migration, it may possibly employ an integrin-independent mechanism in supporting angiogenesis. We also performed the Co-IP assay using an anti- $\alpha v \beta 3$ antibody and failed to co-precipitate endogenous $\beta 3$-endonexin in endothelial cell lysates while endogenous kindlin-2 could be co-precipitated with integrins (not shown). The failure of detecting the interaction between $\beta 3$-endonexin and integrins at the endogenous levels suggests that the integrin $\beta \mathrm{CT}$ in endothelial cells may be predominantly occupied by kindlin-2 (or other binding partners) but not 33 -endonexin, possibly due to its lower binding affinity and/or expression levels. It might be more practical to enrich endogenous $\beta 3$-endonexin in the Co-IP assay by using an anti- $\beta 3$-endonexin antibody. Unfortunately, such an antibody that can be used to precipitate $\beta 3$-endonexin in the cell lysate is currently unavailable in our laboratory. These observations somehow indicate that the proangiogenic effect of endogenous $\beta 3$-endonexin is unlikely through its direct binding to integrins. Nonetheless, exogenous delivery of the $\beta 3$-endonexin-binding $\mathrm{m} \beta \mathrm{CTPs}$ to endothelial cells may effectively sequester endogenous $\beta 3$-endonexin. And possibly, when the expression levels of endogenous integrins in vascular endothelial cells are significantly upregulated under certain pathological conditions, they may also be involved in binding to and sequestering endogenous 33 -endonexin. If so, this may explain why enhanced tumor growth can be observed in mice with deficiency of the $\beta 3$ integrins [12].

The $\beta 3$-endonexin family also includes two other isoforms, $\beta 3$-endonexin-L (170 amino-acids) and NRIF3 
(177 amino-acids), both of which contain the 111 amino-acid $\beta 3$-endonexin at their $\mathrm{N}$-termini [21, 44]. $\beta 3$-Endonexin-L and NRIF3 are almost identical except that the $\mathrm{C}$-terminal 9 residues in $\beta 3$-endonexin- $\mathrm{L}$ are replaced with a 15 amino-acid sequence in NRIF3. Interestingly, $\beta 3$-endonexin- $\mathrm{L}$ does not bind the integrin $\beta 3$ CT [21], suggesting that the $\beta 3$ CT-binding site might be buried inside in the longer $\beta 3$-endonexin isoforms by their $\mathrm{C}$-terminal residues. Therefore, the antiangiogenic ability of the m $\beta C$ TPs may not be relevant to the longer $\beta 3$-endonexin isoforms.

It has been known that the NITY motif in the $\beta 3 \mathrm{CT}$ is an essential binding site for $\beta 3$-endonexin (Table 1) $[21,22]$. In addition, the $\mathrm{N}$-terminal residues proximal to the NITY motif also participate in the binding. Substantially, substitution of the NITY motif with NPTY blunts the binding of $\beta 3 \mathrm{CT}$ to $\beta 3$-endonexin, suggesting that the NPxY motif in the integrin $\beta$ CTs may be not a favorable binding site for $\beta 3$-endonexin. This may explain why only the integrin $\beta 3, \beta 5$ and $\beta 6$ CTs, but not the $\beta 1, \beta 2$ and $\beta 7$ CTs, interact with $\beta 3$-endonexin. In fact, the binding ability of the $\beta 3, \beta 5$ and $\beta 6$ CTs to $\beta 3$-endonexin are not equal. Interestingly, it seems that the binding capacity determines the functional consequence. As we observed, $\mathrm{m} \beta 6 \mathrm{CTP}$, derived from the $\beta 6$ CT with a relatively weak binding to $\beta 3$-endonexin, is also less effective in antiangiogenesis.

As a polypeptide carrying a nuclear localization sequence, $\beta 3$-endonexin can localize in both the nucleus and cytoplasmic region of endothelial cells [27]. A previous study showed that $\beta 3$-endonexin could regulate u-PAR promoter activity through the PEA3/ets binding site [45]. And interestingly, transcriptional factor PEA3 was demonstrated to be able to activate VEGF transcription [46]. Therefore, these findings indicate that $\beta 3$-endonexin may participate in regulating VEGF expression by acting as a transcription cofactor of PEA3 (or some other unidentified ones). Besides, $\beta 3$-endonexin may employ additional mechanisms to support angiogenesis since VEGF can only partially rescue the function (Fig. 8e, f). Hypothetically, the antiangiogenic $\mathrm{m} \beta C$ TPs may direct bind $\beta 3$-endonexin and functionally block its interaction with the downstream targets (transcription factors or DNA sequences). Obviously, further studies are required to delineate the mechanisms.

\section{Conclusions}

Taken together, our findings in this study disclose that certain of peptides derived from the integrin $\beta$ CTs interact with $\beta 3$-endonexin and also are antiangiogenic, revealing a novel antiangiogenic strategy. Since $\beta 3$-endonexin in vascular endothelial cells promotes VEGF expression and cell proliferation, two essential proangiogenic events, we therefore conclude that the antiangiogenic $\mathrm{m} \beta \mathrm{CTPs}$ may directly bind $\beta 3$-endonexin and sequester its proangiogenic property in endothelial cells.

\section{Additional file}

\begin{abstract}
Additional file 1: Figure S1. $\mathrm{m} \beta 3 \mathrm{CTP}$ is membrane-permeable. The peptides of $\mathrm{m} \beta 3 \mathrm{CTP}$ (a) and $\beta 3 \mathrm{CTP}$ (b) were Nterminally conjugated with FITC and used to incubate with HUVECs, and the signal of FITC in HUVECs was evaluated under fluorescent microscopy. Scale bar, $15 \mu \mathrm{m}$. Figure S2. The antiangiogenic peptides do not suppress RM1 cancer cell proliferation. RM1 cancer cells were treated with $\mathrm{m} \beta 3$ CTP or $\mathrm{m} \beta 5 \mathrm{CTP}$ (each at $20 \mu \mathrm{M})$ and their effects on cell proliferation were evaluated using CCK-8 cell proliferation assay. Cells without treatment were used as a control. Figure S3. Both $\mathrm{m} \beta 3 \mathrm{CTP}$ and $\mathrm{m} \beta 5 \mathrm{CTP}$ suppress in vivo tumor growth. RM1 cancer cells were subcutaneously injected into BALB/C nude mice. Mice were treated with $\mathrm{m} \beta 3 \mathrm{CTP}$ and $\mathrm{m} \beta 5 \mathrm{CTP}$ as described in Methods. PBS alone was used as a control. Mice were sacrificed at the end point and tumor tissues were isolated and photographed. Figure S4. m $\beta 3$ CTP and $\mathrm{m} \beta 5$ CTP fail to affect VEGF-induced HUVEC adhesion and migration on vitronectin. a HUVECs were treated with the indicated m $\beta C T P s$ (20 $\mu \mathrm{M})$ and allowed to adhere to immobilized vitronectin for $30 \mathrm{~min}$ in the absence or presence of VEGF $(20 \mathrm{ng} / \mathrm{ml})$. b HUVECs were treated with the indicated $\mathrm{m} \beta C T P s(20 \mu \mathrm{M})$ and allowed to migrate on Transwell membrane coated with vitronectin for $8 \mathrm{~h}$ in the presence of VEGF (20 $\mathrm{ng} / \mathrm{ml})$. The adhered and migrated cells were fixed, stained, photographed and counted ( $\left.{ }^{*}, p<0.05 ;{ }^{*}, p<0.01\right)$. Figure $\mathbf{S 5}$. The antiangiogenic $m \beta C T P s$ and siRNA against $\beta 3$-endonexin suppress HUVEC proliferation. HUVECs were treated with the indicated m $\beta C T P s$ (a) or siRNA against $\beta 3$-endonexin (b). Their effects on cell proliferation were evaluated using the MTT assay $\left(^{* *}, p<0.01\right)$. (PDF $230 \mathrm{~kb}$ )
\end{abstract}

\section{Abbreviations \\ $C T$ : Cytoplasmic tail; m $\beta C T P$ : membrane-permeable $\beta$-integrin cytoplasmic tail peptide; VEGF: Vascular endothelial growth factor; $\beta C T P$ : $\beta$-integrin cytoplasmic tail peptide}

\section{Funding}

This work was supported by grants from the NNSFC $(31571177,31370748$, 31500618, 31770967).

Availability of data and materials

Please contact the corresponding author for all data requests.

\section{Authors' contributions}

$Z C, X S, Y C, Z X, Y B, C M, W D, K M, J G$ and ZX contributed to acquisition of the data; $Z X$ and YQM designed the experiments, analysis of the data and wrote the manuscript. All authors read and approved the final manuscript.

Ethics approval and consent to participate

All animal handling and experiments were approved by the IACUC of Shanghai University School of Life Sciences.

Consent for publication

Not applicable.

\section{Competing interests}

The authors declare that they have no competing interests.

\section{Publisher's Note}

Springer Nature remains neutral with regard to jurisdictional claims in published maps and institutional affiliations.

\section{Author details}

'School of Environmental and Chemical Engineering, Shanghai University, Shanghai, China. ${ }^{2}$ School of Life Sciences, Shanghai University, Shanghai, China. ${ }^{3}$ Blood Research Institute, Blood Center of Wisconsin, part of Versiti, 8727 Watertown Plank Rd, Milwaukee, WI 53226, USA. 
Received: 19 March 2018 Accepted: 19 June 2018 Published online: 03 July 2018

\section{References}

1. Hynes RO. Integrins: bidirectional, allosteric signaling machines. Cell. 2002; 110:673-87.

2. Ginsberg MH, Loftus JC, D'Souza S, Plow EF. Ligand binding to integrins: common and ligand specific recognition mechanisms. Cell Diff Dev. 1990; 32:203-13.

3. Tucker GC. Integrins: molecular targets in cancer therapy. Curr Oncol Rep. 2006;8:96-103.

4. Avraamides CJ, Garmy-Susini B, Varner JA. Integrins in angiogenesis and lymphangiogenesis. Nat Rev Cancer. 2008;8:604-17.

5. Atkinson SJ, Ellison TS, Steri V, Gould E, Robinson SD. Redefining the role(s) of endothelial alphavbeta3-integrin in angiogenesis. Biochem Soc Trans. 2014;42:1590-5.

6. Brooks PC, Clark RA, Cheresh DA. Requirement of vascular integrin à vá 3 for angiogenesis. Science. 1994;264:569-71.

7. Brooks PC, Montgomery AM, Rosenfeld M, Reisfeld RA, Hu T, Klier G, Cheresh DA. Integrin à V á 3 antagonists promote tumor regression by inducing apoptosis of angiogenic blood vessels. Cell. 1994;79:1157-64.

8. Brooks PC, Stromblad S, Klemke R, Visscher D, Sarkar FH, Cheresh DA. Antiintegrin alpha $\vee$ beta 3 blocks human breast cancer growth and angiogenesis in human skin. J Clin Invest. 1995;96:1815-22.

9. McNeel DG, Eickhoff J, Lee FT, King DM, Alberti D, Thomas JP, Friedl A, Kolesar J, Marnocha R, Volkman J, et al. Phase I trial of a monoclonal antibody specific for alphavbeta3 integrin (MEDI-522) in patients with advanced malignancies, including an assessment of effect on tumor perfusion. Clin Cancer Res. 2005;11:7851-60.

10. MacDonald TJ, Taga T, Shimada H, Tabrizi P, Zlokovic BV, Cheresh DA, Laug WE. Preferential susceptibility of brain tumors to the antiangiogenic effects of an alpha(v) integrin antagonist. Neurosurgery. 2001;48:151-7.

11. Gilbert MR, Kuhn J, Lamborn KR, Lieberman F, Wen PY, Mehta M, Cloughesy $T$, Lassman AB, DeAngelis LM, Chang S, Prados M. Cilengitide in patients with recurrent glioblastoma: the results of NABTC 03-02, a phase II trial with measures of treatment delivery. J Neuro-Oncol. 2012;106:147-53.

12. Hodivala-Dilke KM, McHugh KP, Tsakiris DA, Rayburn H, Crowley D, UllmanCullere M, Coller BS, Teitelbaum S, Hynes RO. á 3 -integrin-deficient mice are a model for Glanzmann thrombasthenia showing placental defects and reduced survival. J Clin Invest. 1999;103(2):229-38.

13. Alghisi GC, Ponsonnet $L$, Ruegg $C$. The integrin antagonist cilengitide activates alphaVbeta3, disrupts VE-cadherin localization at cell junctions and enhances permeability in endothelial cells. PLoS One. 2009:4:e4449.

14. Reynolds AR, Hart IR, Watson AR, Welti JC, Silva RG, Robinson SD, Da VG, Gourlaouen M, Salih M, Jones MC, et al. Stimulation of tumor growth and angiogenesis by low concentrations of RGD-mimetic integrin inhibitors. Nat Med. 2009;15:392-400.

15. Stupp R, Hegi ME, Gorlia T, Erridge S, Grujicic D, Steinbach JP, Wick W, Tarnawski R, Nam D, Weyerbrock A, et al. Cilengitide combined with standard treatment for patients with newly diagnosed glioblastoma withmethylated MGMT promoter (CENTRIC EORTC 26071-22072 study): a multicentre, randomised, openlabel, phase 3 trial. Lancet Oncol. 2014;15(10):1100-8.

16. Qin J, Vinogradova O, Plow EF. Integrin bidirectional signaling: a molecular view. PLoS Biol. 2004:2:e169.

17. Ma YQ, Qin J, Plow EF. Platelet integrin alpha(llb)beta(3): activation mechanisms. J Thromb Haemost. 2007:5:1345-52.

18. Tadokoro S, Shattil SJ, Eto K, Tai V, Liddington RC, de Pereda JM, Ginsberg $\mathrm{MH}$, Calderwood DA. Talin binding to integrin á tails: a final common step in integrin activation. Science. 2003;302:103-6.

19. Shi X, Ma YQ, Tu Y, Chen K, Wu S, Fukuda K, Qin J, Plow EF, Wu C. The MIG2/integrin interaction strengthens cell-matrix adhesion and modulates cell motility. J Biol Chem. 2007;282:20455-66.

20. Ma YQ, Qin J, Wu C, Plow EF. Kindlin-2 (Mig-2): a co-activator of beta3 integrins. J Cell Biol. 2008;181:439-46.

21. Shattil SJ, O'Toole T, Eigenthaler M, Thon V, Williams M, Babior BM, Ginsberg $\mathrm{MH}$. Beta 3-endonexin, a novel polypeptide that interacts specifically with the cytoplasmic tail of the integrin beta 3 subunit. J Cell Biol. 1995;131:807-16.

22. Eigenthaler M, Hofferer L, Shattil SJ, Ginsberg MH. A conserved sequence motif in the integrin beta3 cytoplasmic domain is required for its specific interaction with beta3-endonexin. J Biol Chem. 1997;272:7693-8.
23. Rognoni E, Ruppert R, Fassler R. The kindlin family: functions, signaling properties and implications for human disease. J Cell Sci. 2016;129:17-27.

24. Kracun D, Riess F, Kanchev I, Gawaz M, Gorlach A. The beta3-integrin binding protein beta3-endonexin is a novel negative regulator of hypoxiainducible factor-1. Antioxid Redox Signal. 2014;20:1964-76.

25. Bialkowska K, Ma YQ, Bledzka K, Sossey-Alaoui K, Izem L, Zhang X, Malinin N, Qin J, Byzova T, Plow EF. The integrin coactivator kindlin-3 is expressed and functional in a non-hematopoietic cell, the endothelial cell. J Biol Chem. 2010;285:18640-9.

26. Pluskota E, Dowling JJ, Gordon N, Golden JA, Szpak D, West XZ, Nestor C, Ma YQ, Bialkowska K, Byzova T, Plow EF. The integrin coactivator kindlin-2 plays a critical role in angiogenesis in mice and zebrafish. Blood. 2011;117:4978-87.

27. Besta F, Massberg S, Brand K, Muller E, Page S, Gruner S, Lorenz M, Sadoul K, Kolanus W, Lengyel E, Gawaz M. Role of beta(3)-endonexin in the regulation of NF-kappaB-dependent expression of urokinase-type plasminogen activator receptor. J Cell Sci. 2002;115:3879-88.

28. Gao J, Huang M, Lai J, Mao K, Sun P, Cao Z, Hu Y, Zhang Y, Schulte ML, Jin C, et al. Kindlin supports platelet integrin alphallbbeta3 activation by interacting with paxillin. J Cell Sci. 2017;130(21):3764-75.

29. Green M, Loewenstein PM. Autonomous functional domains of chemically synthesized human immunodeficiency virus tat trans-activator protein. Cell. 1988;55:1179-88.

30. Frankel $A D$, Pabo CO. Cellular uptake of the tat protein from human immunodeficiency virus. Cell. 1988;55:1189-93.

31. Blystone SD, Lindberg FP, Williams MP, McHugh KP, Brown EJ. Inducible tyrosine phosphorylation of the á 3 integrin requires the à $V$ integrin cytoplasmic tail. J Biol Chem. 1996;271:31458-62.

32. Law DA, Nannizzi-Alaimo L, Phillips DR. Outside-in integrin signal transduction. à Illb á 3 -(GPIIb-IIla) tyrosine phosphorylation induced by platelet aggregation. J Biol Chem. 1996;271:10811-5.

33. Ohtoshi A, Maeda T, Higashi H, Ashizawa S, Yamada M, Hatakeyama M. beta3-endonexin as a novel inhibitor of cyclin A-associated kinase. Biochem Biophys Res Commun. 2000;267:947-52.

34. Kumar CC. Integrin alpha $v$ beta 3 as a therapeutic target for blocking tumor-induced angiogenesis. Curr Drug Targets. 2003:4:123-31.

35. Liu Z, Wang F, Chen X. Integrin alpha(v)beta(3)-targeted Cancer therapy. Drug Dev Res. 2008;69:329-39.

36. Bledzka K, Bialkowska K, Nie H, Qin J, Byzova T, Wu C, Plow EF, Ma YQ. Tyrosine phosphorylation of integrin beta3 regulates kindlin-2 binding and integrin activation. J Biol Chem. 2010;285:30370-4.

37. Bledzka K, Liu J, Xu Z, Perera HD, Yadav SP, Bialkowska K, Qin J, Ma YQ, Plow EF. Spatial coordination of kindlin-2 with Talin head domain in interaction with integrin beta cytoplasmic tails. J Biol Chem. 2012;287:24585-94.

38. Cowan KJ, Law DA, Phillips DR. Identification of Shc as the primary protein binding to the tyrosine-phosphorylated á 3 subunit of à IIb á 3 during outside-in integrin platelet signaling. J Biol Chem. 2000;275:36423-9.

39. Jenkins AL, Nannizzi-Alaimo L, Silver D, Sellers JR, Ginsburg MH, Law DA, Phillips DR. Tyrosine phosphorylation of the á 3 cytoplasmic domain mediates integrin-cytoskeletal interactions. J Biol Chem. 1998;273:13878-85.

40. Obergfell A, Eto K, Mocsai A, Buensuceso C, Moores SL, Brugge JS, Lowell CA, Shattil SJ. Coordinate interactions of Csk, Src, and Syk kinases with [alpha] Ib[beta]3 initiate integrin signaling to the cytoskeleton. J Cell Biol. 2002;157:265-75.

41. Liao Z, Kato H, Pandey M, Cantor JM, Ablooglu AJ, Ginsberg MH, Shattil SJ. Interaction of kindlin-2 with integrin beta3 promotes outside-in signaling responses by the alphaVbeta3 vitronectin receptor. Blood. 2015;125:1995-2004.

42. Arias-Salgado EG, Lizano S, Sarkar S, Brugge JS, Ginsberg MH, Shattil SJ. Src kinase activation by direct interaction with the integrin beta cytoplasmic domain. Proc Natl Acad Sci USA. 2003;100:13298-302.

43. Ohira T, Akutagawa S, Usuda J, Nakamura T, Hirano T, Tsuboi M, Nishio K, Taguchi F, Ikeda N, Nakamura $\mathrm{H}$, et al. Up-regulated gene expression of angiogenesis factors in post-chemotherapeutic lung cancer tissues determined by cDNA macroarray. Oncol Rep. 2002;9:723-8.

44. Li D, Desai-Yajnik V, Lo E, Schapira M, Abagyan R, Samuels HH. NRIF3 is a novel coactivator mediating functional specificity of nuclear hormone receptors. Mol Cell Biol. 1999;19:7191-202. 
45. Hapke S, Gawaz M, Dehne K, Kohler J, Marshall JF, Graeff H, Schmitt M, Reuning U, Lengyel E. Beta(3)A-integrin downregulates the urokinase-type plasminogen activator receptor (U-PAR) through a PEA3/ets transcriptional silencing element in the u-PAR promoter. Mol Cell Biol. 2001;21:2118-32.

46. Hua D, Chen B, Bai M, Yu H, Wu X, Jin W. PEA3 activates VEGF transcription in T47D and SKBR3 breast cancer cells. Acta Biochim Biophys Sin Shanghai. 2009;41:63-8.

Ready to submit your research? Choose BMC and benefit from:

- fast, convenient online submission

- thorough peer review by experienced researchers in your field

- rapid publication on acceptance

- support for research data, including large and complex data types

- gold Open Access which fosters wider collaboration and increased citations

- maximum visibility for your research: over $100 \mathrm{M}$ website views per year 